\title{
Thrasymachus on Justice, Rulers, and Laws in Republic I
}

\author{
Stephen Everson
}

One issue of contention amongst scholars of the Republic is whether Thrasymachus initially espouses a conventionalist account of justice, according to which just actions are merely those which are lawful; required, or at least allowed, by the laws passed by the ruler of the state. A further question is then whether his initial conceptions of rulers and laws are positivist ones, such that to be a ruler or law of a state is simply determined by the state's constitution (or indeed by the ruler's ability to enforce obedience). At 340c Thrasymachus effectively rejects such positivism by placing a condition on being a ruler that one should be exercising the art of ruling and on being a law that it should work to the ruler's interest. Some have maintained that this works to clarify his initial account and so shows that he was never a positivist about rulers and laws. In this paper I argue against such an understanding of Thrasymachus' argument and explore the problems which beset the position he is, on my reading, forced into by Socrates' objection to his opening claim that justice is what is in the interest of the stronger and the argument he first gives to support it.

According to Thrasymachus at Republic I 338c, 'justice is nothing other than the advantage of the stronger'. At 338e, he then declares that 'justice is the same in all cities, the advantage of the established rule' ( 339a2). Half-a-Stephanus-page further on, we find him endorsing as his own the claim that 'whatever laws [the rulers] make must be obeyed by their subjects, and this is justice' (339c) and then, after tussling with Socrates for a page and a half, he repeats his claim that it is just to do what is to the advantage of the stronger (341a). Finally, at 343c, he maintains as if obviously true that 'justice is really the good of another' and this turns his attention from considering the relations between rulers and their subjects to those between people more generally. That Plato should put such a swarm of different characterisations of justice into Thrasymachus' mouth in such short order hardly seems designed to give his reader confidence that they collectively manifest a single and coherent view of justice, let alone a compelling or even plausible one. Nevertheless, 
whilst Plato's commentators have generally been quick to dismiss Socrates' first two interlocutors in Republic I as intellectually inadequate to the task of joining him in the investigation of justice, they have been much less willing to accept at face value Plato's portrait of Thrasymachus as careless or confused. Indeed, it has become something of a standing challenge to the ingenuity and philosophical acumen of Plato's interpreters to show that Thrasymachus' various claims can be given a reading that renders them consistent without making them intolerably vague.

In an earlier paper, 'The Incoherence of Thrasymachus' (hereafter 'IT'), I argued that that challenge is not one that the interpreter of the Republic can, or should even try to, meet. Not only are the claims about justice made by Thrasymachus in the first book of the Republic actually inconsistent, they are intended by Plato to be so. ${ }^{1}$ In fact, so I argued, not only is there a fault-line between the claims that justice is what is advantageous the stronger and that it is the good of another, but the first of these is used to articulate two different positions which are also themselves inconsistent. Amongst a number of attempts by commentators to defend Thrasymachus' philosophical honour against my charges of confusion and incoherence, one of the most sophisticated and textually attentive has come from C.D.C. Reeve. On Reeve's account of Republic I, not only is Thrasymachus not, as I had it, 'the sort of person who is not argumentatively careful and who is capable of holding what are in fact contradictory views without realising it' (IT, p. 130), he is actually a careful and indeed powerfully insightful political thinker. ${ }^{2}$ His account of justice, according to Reeve, 'is a coherent and resourceful blend... of ethical realism and semantic conventionalism, which identifies justice in each city with what is advantageous to its stronger ruler, and the semantic content of "justice" with what its particular laws prescribe'. ${ }^{3}$ Far from accepting that Plato uses Thrasymachus to suggest that the various positions he conflates are each likely to prove attractive to the kind of incautious thinker who would conflate them, Reeve argues that Plato takes Thrasymachus to hold consistently to an account of justice that makes him a

\footnotetext{
${ }^{1}$ S. Everson, 'The Incoherence of Thrasymachus', Oxford Studies in Ancient Philosophy XVI (1998), 99-131.

2 C.D.C. Reeve, 'Glaucon's Challenge and Thrasymacheanism', Oxford Studies in Ancient Philosophy XXXIV (2008), 69-103. All references to Reeve will be to this paper unless specified otherwise.
}

${ }^{3}$ Reeve, p. 98 
'worthy opponent' of the Socrates of the Republic, and therefore, it would seem, of Plato himself. $^{4}$

Using Reeve's riposte to IT as a spring-board, I want here to explore in greater depth Thrasymachus' arguments at 338-341 for his claim that justice is what is to the advantage of the stronger and in particular the effect of his introduction of the 'precise' notion of a ruler as one incapable of making legislative errors. I shall argue that, despite Reeve's endeavours to reconcile what Thrasymachus says before this with the position he articulates in doing so, that new position does indeed force Thrasymachus into making claims that are inconsistent with the argument he initially gives for his opening statement about what justice is. However, although the arguments that Thrasymachus offers for that statement are, despite what he says, different, the content of that statement itself is unaffected by this. Whether the effect of this is to diminish the confusion in Thrasymachus' position I am not sure - certainly, as I shall argue in the final section it does nothing to touch the central incoherence in his claims about what justice is.

I shall divide 338-341 into two parts. The first- $[\mathrm{A}]$ - runs from 338c, when Thrasymachus offers his answer to the question 'What is justice?', to 340c, when Socrates asks him whether he actually wanted to say not that justice is what is to the advantage of the stronger but merely that it is what the stronger believes to be to their advantage. The second- $[\mathrm{B}]$ - runs from 340a to 341a, during which Thrasymachus rejects that proposal and elaborates a view according to which rulers are to be understood as experts incapable of making errors in ruling and ends up claiming to reaffirm the answer he gave at the start. A key question to be addressed is whether the position articulated by Thrasymachus in $[\mathrm{A}]$ is the same as that which he elaborates in [B].

$$
-\mathrm{II}-
$$

'Listen, then, I say that justice is nothing other than the advantage of the stronger,' says Thrasymachus at 338 a giving his 'fine answer' to the question of what justice is. As an answer to that question, however, it is far from perspicuous and Socrates duly professes himself unable to evaluate it. To clarify what it is supposed to mean, Thrasymachus appeals to the behaviour of the rulers of states:

\footnotetext{
${ }^{4}$ Reeve, p. 86
} 
Don't you know that some states are ruler by a tyranny, some by a democracy, and some by an aristocracy?

Of course.

And in each state this element is stronger, namely, the ruler.

Certainly.

And each makes laws to its own advantage. Democracy makes democratic laws, tyranny makes tyrannical laws, and so on with the others. And they declare what they have made - what is to their own advantage - to be just for their subjects, and they punish anyone who goes against this as lawless and unjust. This, then, is what I say justice is, the same in all states, the advantage of the established rule. Since the established rule is surely stronger, anyone who reasons correctly will conclude that the just is the same everywhere, namely, the advantage of the stronger. ${ }^{5}$ (338d-339a)

This is sufficient for Socrates to begin to examine Thrasymachus' opening claim to see whether it is correct. His first move is to make sure that Thrasymachus is, as he takes him to be, committed to the claim that it is just to obey the rulers, which then provides the ground for Socrates' attack:

Tell me, don't you also say that it is just to obey the rulers?

I do.

And are the rulers in all cities infallible, or are they liable to error?

No doubt they are liable to error.

When they undertake to make laws, therefore, they make some correctly, others incorrectly? I suppose so.

And a law is correct if it prescribes what is to the rulers' own advantage and incorrect if it prescribes what is to their disadvantage? Is that what you mean?

It is.

And whatever laws they make must be obeyed by their subjects, and this is justice?

Of course.

Then, according to your account, it is just to do not only what is to the advantage of the stronger, but also the opposite, what is not to their advantage. (339b-d)

We can discern three relevant claims in Thrasymachus' opening presentation:

(1) Justice is nothing other than what is to the advantage of the stronger.

(E) The rulers of states always enact legislation that is to their advantage.

(2) Justice is the advantage of the established rule.

To these we can add the claim which Thrasymachus does not initially put forward himself, but which his argument assumes (and which Socrates makes explicit):

(3) Justice is obeying whatever laws are enacted by the ruler.

Socrates' objection works by calling (E) into doubt, so that Thrasymachus' commitment to (3) will then undercut his ability to maintain (1): if it is just to obey whatever laws are

\footnotetext{
${ }^{5}$ I have generally stuck by Reeve's own translations of the Republic from J.M. Cooper (ed.), Plato: Complete Works (Indianapolis/Cambridge, 1997). There have been, however, a few occasions when the urge to revise has been too great to resist.
} 
enacted by the ruler of a state, and some legally required actions are to the disadvantage of the ruler, just actions are as a class no more to the advantage of the ruler than they are to their disadvantage.

$$
- \text { III - }
$$

To get from (3) to (2), and hence to (1), Thrasymachus appeals to the legislative behaviour of rulers. The ruling element in a state enacts legislation that is to its own advantage and so if one acts in a way that is required by the law one will act to the advantage of the rulers who enacted it. Socrates' objection is straightforward. Even if rulers always intend to enact laws that are to their own advantage, it does not follow that the laws they actually enact are to their advantage, since rulers can make mistakes when legislating. Thrasymachus' argument would only go through if rulers were infallibleand this is what, of course, Thrasymachus precisely does then assert to save his argument. 'Do you think I'd call someone who is in error stronger at the moment he errs,' he demands, and proceeds to distinguish a precise sense of 'ruler', according to which rulers are legislatively infallible. To be a ruler is to exercise the art, the techne of ruling, and no incorrectly enacted law will be the result of the exercise of that art; a ruler who makes a mistake is no ruler at all.

Strictly speaking, then, a ruler can never make mistakes, since in making a mistake they would not comply with the conditions for being a ruler:

But the most precise answer is this: A ruler, insofar as he is a ruler, never makes errors and unerringly decrees what is best for himself, and this his subject must do. Thus as I said from the first, it is just to do what is to the advantage of the stronger. (340e-341a)

Once again, Socrates is prompted to ask for clarity as to what Thrasymachus is saying:

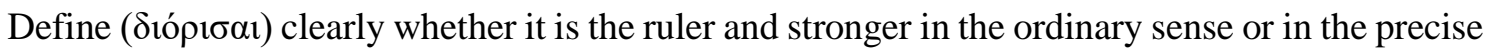

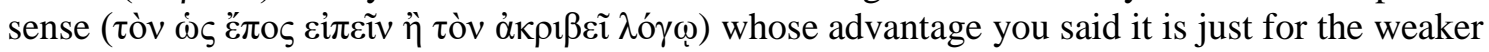
to promote as the advantage of the stronger.

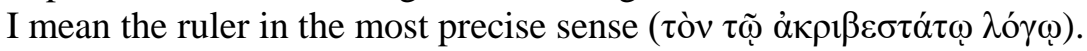

What this alerts the reader to, of course, is the possibility of ambiguity in Thrasymachus' definition of justice. Thrasymachus concedes that when he first admitted (at 339c) that rulers are not infallible, he was using the term 'ruler' loosely but now maintains that his 
statement that justice is the advantage of the stronger, that is the ruler, the term is to be understood in its precise usage.

Socrates is not being pedantic in checking this last point, since the upshot of Thrasymachus' appeal to a precise use of 'ruler' to secure his claim that rulers are infallible is that the truth-value of a sentence containing the term will depend on whether the term is used loosely or precisely and this will not be apparent on its face. ${ }^{6}$ The potential for confusion that arises in the Greek is not lost in translation and it will help to have a device to mark the difference in senses that the word has in its uses. So as to avoid confusion, I shall follow Reeve and talk of 'E-rulers' and 'T-rulers', where the first conforms to Thrasymachus' loose and the second to his precise use of the term. ${ }^{7}$

Thrasymachus is clear that the claim he is committed to from $341 \mathrm{a}$ is that justice is to the advantage of the T-ruler. What is less clear is whether we can take him to have made the same claim at 339a when he appeals to the behaviour of those in power in states to clarify his opening definition of justice. In IT, I argued that we cannot. The account of justice Thrasymachus offers in $[\mathrm{A}]$ is what has come to be called a 'conventionalist' one: 'to say someone is required by justice to perform a certain action is only to say that he is required by the law to do so' (p. 107). Laws are what those in power in a state institute to regulate the actions of the citizens or inhabitants of that state and since what those who have power will seek to do in legislating is to regulate actions so that their interests are served, when citizens act as the laws prescribe they will act to the advantage of the rulerand that will be, in the new jargon, the E-ruler. Although Thrasymachus seeks to defend that claim against Socrates' challenge of fallibility by introducing, or at least appealing to, the notion of a T-ruler, not only does he thereby change it, so that he is not defending the claim he pretends or at least takes himself to be, but he also shifts the account of justice itself away from being the conventionalist one he first articulated. ${ }^{8}$ In now placing what is in effect a normative condition on what it is for someone to be a ruler- that they

\footnotetext{
${ }^{6}$ One generally needs to be very wary of translations of Plato and Aristotle which invoke the notion of sense but, even duly wary, we can accept the use of 'sense' in Reeve's translation above with a fairly clear conscience.

${ }^{7}$ In IT, I followed Reeve's earlier discussion in his Philosopher-Kings in using 'ruler' and 'Ruler' to effect this distinction (see C.D.C. Reeve, Philosopher-Kings (Princeton/Oxford, 1998) p. 12f). In the later paper, Reeve changes his terminology to that which I have adopted here. One advantage of the new over the earlier terminology is that the new terms do not create ambiguity when used at the beginning of sentences.
}

${ }^{8}$ IT, section VII. 
should be exercising expertise in instituting a law - to determine whether an action is just will now itself require making a normative judgement as to whether any candidate law by reference to which it is to be evaluated actually served the interests of the supposed ruler who instituted it.

Reeve, in contrast, finds no such change in Thrasymachus' position at 340c: according to Reeve, his claim to be making precise what he has already said is to be accepted on its face rather than as masking a move he has been forced into to meet Socrates' objection. It should not be seen, that is, as introducing the new notion of the ruler-expert, but as clarifying the concept of a ruler which is already in play. On his view, Thrasymachus' position is innocent of conventionalism throughout so that $[\mathrm{A}]$ and $[\mathrm{B}]$ taken together present no internal inconsistency.

Many of Plato's commentators have regarded the position Thrasymachus elaborates in [B] to be a fairly desperate one, avoiding the force of Socrates' objection only at the cost of what Julia Annas for instance writes off as 'a very counter-intuitive position' which 'flouts our beliefs about doctors, rulers, etc. ${ }^{9}$ Of course, the more counter-intuitive and the less well motivated is Thrasymachus' position here, the more plausible it will be to see him as adopting it merely to stave off Socrates' challenge. We can distinguish two core claims - that rulers are a type of craftsman ( $\delta \eta \mu$ เov $\rho \gamma$ ó $\varsigma$ ) and then a conceptual claim about craftsmen generally; that no-one is a craftsman of whatever kind when they are making an error in respect of their craft. In fact, neither of those claims is unmotivated and even the second may have been less counter-intuitive in historical context than it now strikes us. How theoretically stable this position is deserves a more substantial, and so separate, treatment than I can offer here. ${ }^{10}$

My contention that Thrasymachus changes his central thesis so that he ends up defending something other than he intends or claims to have been defending does not then rest on a principled objection either to the notion of a T-ruler or even its theoretical

\footnotetext{
9 Julia Annas, An Introduction to Plato's Republic (Oxford, 1981), p. 43

${ }^{10} \mathrm{~A}$ very interesting recent treatment of the notion of $\tau \dot{\varepsilon} \chi v \eta$ and its possession that Thrasymachus employs is Tamer Nawar 'Thrasymachus' Unerring Skill and the Arguments of Republic 1', Phronesis 63 (2018), 359-91, who nicely places this in the context not only of the Euthydemus and Charmides, but also some of the Hippocratic authors. Although I'm greatly in sympathy with much of what Nawar says to show that the infallibilist conception of a skill is indeed theoretically grounded, I remain dubious that it can do the work Thrasymachus needs it to do in specifying what it is to be a ruler. I shall not pursue that here, however.
} 
utility. What is at issue is whether one can interpret Thrasymachus' arguments through [A] and [B] so that he is making claims about T-rulers throughout. To use the terms introduced earlier, are the conception of an E-ruler and a T-ruler different conceptions of the same concept or are they conceptions of different concepts? ${ }^{11}$ If the first, then the restrictions which Thrasymachus places on being a T-ruler will simply elucidate what it is to be a ruler-'E-ruler' and 'T-ruler' will have been terms introduced to clarify his arguments, but can then simply fall away to leave one talking, as he does, simply of rulers. Alternatively, if those restrictions serve to introduce a new concept, then one will not be able to lay out Thrasymachus' arguments through $[\mathrm{A}]$ and $[\mathrm{B}]$ without such a device of disambiguation. At any occasion when he uses the term, it will be appropriate to ask, as Socrates does at $341 \mathrm{~b}$, which sense the word is carrying in order to know what he is talking about. ${ }^{12}$

It is common ground that Thrasymachus' argumentative strategy in $[\mathrm{A}]$ is to derive (2) from (3) and (E), and then (1) from (2). ${ }^{13}$ It is also common ground that in [B] Thrasymachus takes himself to be defending (1) and his argument for it against Socrates' objection that since rulers will sometimes make mistakes when they enact laws, not every

\footnotetext{
${ }^{11}$ My distinguishing between 'concept' and 'conception' conforms to one standard usage — as set out, for instance, by David Wiggins in his Sameness and Substance Renewed (Cambridge, 2001), pp. $10-11$.

${ }^{12}$ It is perhaps worth my acknowledging that, for ease of discussion, I am allowing myself to talk as if Socrates and Thrasymachus were using the English words that serve here to translate the Greek words they actually do use. (One is reminded of the Oxford Greats candidate who declared with some impatience that if Aristotle had intended ' $\varepsilon$ b $\delta \alpha \mu$ ovía' to mean happiness, he would have said so.) Even if this is not entirely felicitous, it does not, I think, result in any confusion. This is, of course, not the only place in Plato where there is a question as to whether the progress of the discussion clarifies an existing concept or merely introduces a new one. A prime example of that is Plato's account of justice later in the Republic itself, where he has been charged with setting out to defend one concept of justice-'vulgar-justice'-and defending something quite different-'platonic-justice'. Here the defender of Plato needs to show that the conception of vulgar-justice and that of platonic-justice are both conceptions of the concept justice. For such a defence, see my own 'Justice and Just Actions in the Republic,' in B. Morison and K. Ierodiakonou (edd.), Episteme, etc. (Oxford, 2012), 249-76.

${ }^{13}$ Common ground, that is, between Reeve and myself. Others read [A] so that Thrasymachus derives (3) from (1) - see, for instance, Annas, Introduction, 39-40.
} 
law will in fact serve the interests of the ruler who enacts it. Using the terminology of Erulers and T-rulers, we can take the claim Thrasymachus assents to at 339a to be

(2a) Justice is what is to the advantage of the (E)-ruler,

and his implied claim at 341a to be

(2b) Justice is what is to the advantage of the (T)-ruler.

So, are (2a) and (2b) the same claim expressed in different terms or are they actually different claims? ${ }^{14}$

'E-ruler' is to have the sense that is conferred on 'ruler' when people are talking loosely - that is, without the constraint of the possession of expertise. In IT, I argued that the conception of an E-ruler must indeed be what we can call a positivist one, where a ruler is merely someone who, or some group that, has the power in a state to direct the behaviour of the citizens of the state. This goes with a similarly positivist understanding of the laws of a state: a law will be a directive passed by whoever is in power in whatever is the way specified by the state's constitution (which in the case of tyranny may be simply the tyrant's issuing decrees or orders). What's key is that none of these concepts are normatively constrained. One doesn't need to evaluate a person to determine whether they are a ruler or a directive to determine whether it is a law. And from the facts about what laws are passed in a state by those with the power to pass them - the E-rulers - one can, given (3), determine whether an action is just or unjust and, again, without needing to appeal to any evaluation of the action. ${ }^{15}$ Given (E) - the rulers of states always enact legislation that is to their advantage - one thing all just actions at least have in common is that they are to the advantage of the E-rulers who enacted the laws to which they conform. Reeve, opposing this positivist reading of Thrasymachus' position in [A], finds

\footnotetext{
${ }^{14}$ Finding both (2a) and (2b) in the text involves a degree of smoothing out. What Thrasymachus actually claims at 339a is that justice is what is in the interest of 'the established rule' ( $\tau$ ò $\tau \tilde{\eta} s$

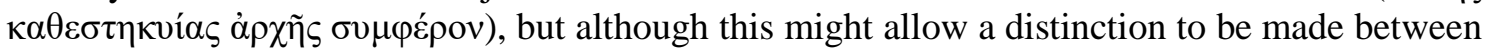
a ruling group (say, the aristocracy) and the members of that group (those who are the aristocrats at any time), it is clear that Thrasymachus does not intend any such distinction, so that it is harmless to take him to be talking of the ruler or rulers here. At 341a he moves immediately from his attempt to show that rulers never make mistakes, so that they only pass laws that are to their advantage, to the claim that justice is what is to the advantage of the stronger and clearly that move relies on the implicit premise that justice is what is to the advantage of the ruler.

${ }^{15}$ In the light of this, when Thrasymachus demands that Socrates should say what justice is at $336 \mathrm{c}$ it is not unreasonable to take his prohibition of appealing to various evaluative concepts as an indication of methodological principle rather than a denial in advance that justice is something valuable in whatever way: 'Give an answer yourself, and tell us what you say the just is. And don't tell me that it's the right, the beneficial, the profitable, the gainful, or the advantageous, but tell me clearly and exactly what you mean' $(336 \mathrm{c}-\mathrm{d})$.
} 
no hint there of either conventionalism about justice or positivism about rulers and lawsand neither, he maintains, does Socrates, whose challenge, he thinks, actually requires that Thrasymachus' underlying account of what it is to be an E-ruler is not conventionalist in the way I've just characterised.

Once Thrasymachus has sufficiently clarified what he means by (1) for Socrates to be able to examine whether it is true and also confirmed that he accepts (3), Socrates poses the question as to whether (E)-rulers can make mistakes in enacting legislation:

Tell me, don't you also say that it is just to obey the rulers?

I do.

And are the rulers in all cities infallible, or are they liable to error?

No doubt they are liable to error.

When they undertake to make laws, therefore, they make some correctly, others incorrectly? I suppose so.

And a law is correct if it prescribes what is to the rulers' own advantage and incorrect if it prescribes what is to their disadvantage? Is that what you mean?

It is. $(339 b-c)$

So, a ruler will make a law incorrectly ( $\mu \grave{\eta}$ o $\rho \theta \tilde{\omega} \varsigma$ ) if the law is not in fact to their own advantage - and given (3), when a citizen or subject obeys that law, their action will be just but not to the ruler's advantage.

Socrates' argument here relies on being able to make sense of a ruler's making a mistake and it is this which Reeve takes to show that at least Socrates thinks that Thrasymachus is no conventionalist:

In constructing this trap... Socrates recognizes from the beginning that Thrasymachus has a standard of correctness for E-laws in mind, namely, that they 'prescribe what is advantageous for the rulers themselves' (339 c7-8). This is an embarrassment for Everson's view that E is conventionalist, since if it were, there could be no such standard and we would have to wonder why Plato sends Socrates off on so wrong a foot. ${ }^{16}$

Reeve takes it as being obvious here that a conventionalist or positivist conception of rulers and laws will not tolerate a standard of correctness for laws. And, taking that to be obvious, he doesn't provide any argument to confirm that appearance. One possible motivation, however, might be this: the point of a positivist account of law is that the conditions for what is to count as a law are local. What will count as a law in the France of Louis XIV is very different from what will count as a law in fifth-century Athens or contemporary Scotland. And any statement of a universal standard for the correctness of

\footnotetext{
${ }^{16}$ Reeve, p. 89
} 
laws will stand in conflict with that. If that is what Reeve has in mind, an immediate point to make is that whilst the positivist holds that what will secure the status of an order or a prescription can, and does, vary between different states (or, perhaps better because more general, between different political entities), what it is to have that status should not differ. That is, the adoption of a positivist account of laws does not preclude the ability to say what a law is.

Take, for example, Andrei Marmor's exposition of the 'command theory of law' that forms the roots of modern legal positivism as developed, say by, John Austin:

The command theory of law... assumes, quite plausibly, that laws consist of instructions or directives issued by some people to direct the conduct of others. Now, of course, there are many contexts in some people tell other people what to do or how to behave. What makes action-guiding instructions legal has to do with the origins and the function of the guidance: If the guidance emanates from the political sovereign and purports to function as an exercise of sovereignty, then it is law... So perhaps that is all there is to it: Instructions or commands of the political sovereign are what we call law. ${ }^{17}$

That one should take the central case of law-giving to be that of a sovereign issuing commands to their subjects is clearly in sympathy with Thrasymachus' conception of how the rulers of states govern through enacting laws. It allows that no more is needed for a command to have legal status than that it should be issued by a sovereign but it also allows for different states to have different conventions or, more formally, constitutions that would place further restrictions on how a sovereign might issue a command if it is to count as a law. All of this is consistent with positivism but also with the ability to specify in quite general terms what a law is (or what it is for an instruction or command to be a law) _ and, if one can state what a law is, one can also state in quite general terms what may make for better or worse laws. There would be no bar, for instance, to positing a standard of good drafting or clear formulation: If one is going to enact a law or even issue an order, it should be drafted in such a way that those to whom it applies should be able to tell what they have to do to comply with it. A law which because of failures of drafting can leave that open will be a defective law not least (though not only) because it will fail properly to secure whatever was the objective for its enactment.

Reeve might retort to this that whilst a standard of precise formulation could indeed by affirmed as applying to all laws of any state without going against a positivist account

\footnotetext{
${ }^{17}$ Andrei Marmor, Philosophy of Law (Princeton and Oxford, 2011), p. 36. Sovereigns here may be individuals, but they may also be institutions, such as the California legislature.
} 
of law, this is because it applies a standard of a relevantly different kind to that which is applied by Thrasymachus at 339c. Any candidate for being a law will need to be formulated and so it is unproblematic to describe ways in which its formulation should be better or worse. Consider, in contrast, Austin's statement of the central claim of his positivist account:

The existence of law is one thing; its merit and demerit another. Whether it be or be not is one enquiry; whether it be or be not conformable to an assumed standard, is a different enquiry. ${ }^{18}$

What Austin has in mind here is a moral or evaluative standard. He is taking a stand against, for instance, natural-law conceptions according to which an unjust law is no law at all. If Thrasymachus' standard for legal correctness is that the law should be to the advantage of the ruler that is to impose an evaluative standard for legal correctness.

What is at least moot, however, is whether at $339 \mathrm{c}$ this is accepted as a standard of the kind that Austin rejects. What made the suggested standard of precise formulation acceptable to a positivist was not merely that it regulates a feature of any candidate law but that it works as a criterion for judging how good any law is as a law. What it does not provide is a standard for judging whether any command or instruction is a law at all. One can still make perfect sense of the possibility that a law is a bad law because it is badly drafted. So what Reeve needs to establish is not merely that Thrasymachus accepts that being to the advantage of the E-ruler is a standard for the correctness of a law, but that he accepts it as a standard for being a law at all. In Austin's terms, it needs to pertain to a law's existence and not merely to its merit or demerit.

Now, although Thrasymachus does not re-state the standard once he has introduced the notion of the T-ruler, it is certainly an implication of what he says at 341a that he would accept this as an existential standard. The decrees that a subject must obey are those issued by a T-ruler who is exercising their expertise in issuing them and these will necessarily be ones that are to the advantage of that T-ruler. But obviously Reeve cannot appeal to this as support for taking the standard in the same way when it is stated at 399c without begging the question. So one needs to consider the dialectical context of that statement if one is to determine whether it is there given as an existential or a critical standard for laws.

\footnotetext{
${ }^{18}$ John Austin, The Province of Jurisprudence Determined. Ed. W.E. Rumble, (Cambridge,
} 1995), p. 157 
Seen in its context, however, it is clear that Thrasymachus does not think that an incorrect law is no law at all. Until he understands that his easy acceptance of the claim that rulers - E-rulers - can make mistakes in legislating will subvert his claim about what justice is, he is entirely untroubled by the idea that sometimes a ruler may mistakenly enact a law that is to their disadvantage and assents to the claim that "whatever laws the rulers make' - i.e. whether they are laws that are correct or incorrect—'they must be acted

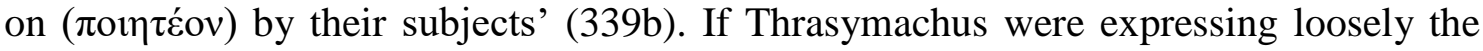
precise notions of the T-ruler and of the T-law that he will go on to articulate in order to escape Socrates' trap, he would surely have been prompted by Socrates' questions themselves to have given different answers to them and not waited to have Socrates explain - twice - why the answers he does give cause the problems for him that they do. Up until [B], then, Thrasymachus sees no tension in the possibility of a law that is nevertheless incorrectly enacted in that its regulation of behaviour does not actually work to the E-ruler's benefit. One might still wonder, however, whether even if the standard for the correctness of laws is critical rather than existential this might be in tension with a positivist conception of laws and legislation. If there is a single standard for any law according to which one can determine whether it is defective, does that not itself require one to conceive of laws in terms of some necessary evaluative goal that is internal to the practice of law-giving? Should we not see Socrates' assumption that Thrasymachus posits as a standard for the correctness of law that it should benefit the E-ruler a recognition that Thrasymachus is not, even in [A], operating straightforwardly with a positivist conception of laws and then Thrasymachus' acceptance of that standard as confirmation that he indeed is not?

Socrates' challenge, of course, picks up on (E), Thrasymachus' claim at 338e that Erulers always enact laws that are to their advantage. Whilst this might work as a statement of E-rulers' purpose, their fallibility means that they will not always succeed in securing their advantage and when they don't the law they enact will not achieve the purpose they had for it. Making law is, on any account, a purposeful activity and whenever a ruler enacts a law, they will have a goal in doing so. On a positivist reading of [A], according to which someone will be a ruler if they have the power to enact and to enforce legislation and a law will have force just if it has been enacted according to the correct constitutional procedures, Thrasymachus believes that those who have the power to enact laws always want to regulate the behaviour of their subjects to further the interests of the ruler; whenever that is their purpose (which happens to be always), any law which fails to do 
this will be defective. The standard for success is set just by the goal the legislator happens to have: of course, it is not accidental that legislators have, when legislating, the goal of furthering their interests, but that is not because they are legislators or because they are legislating but simply because they are human and humans always seek, if unconstrained, to further their own interests. There is nothing unstable, then, in thinking that every law which fails to further the interests of the ruler signals a failure of skill on the part of the legislator whilst denying that this stops them from enacting a law or from being a legislator. Even if one thinks that legislating is an essential activity of being a ruler, one can allow that legislating is an activity that requires skill without making possession of that skill essential to being a ruler.

So, that Thrasymachus thinks that a law will be badly made if it doesn't further the interests of the E-ruler is consistent with his holding a positivist conception of laws, but it does not in itself, of course, require that. It is not an embarrassment for a conventionalist interpretation of [A], but neither does it in itself secure it. The 'in itself 'is important there, since the considerations which restrict the standard so that it is critical rather than existential also present a difficulty for a non-conventionalist reading of Thrasymachus' argument. The possibility that an E-ruler may legislate badly and enact a law that is in fact not to their advantage, but which, being a law, must be obeyed by their subjects, entails that a defective law is nevertheless a law-and also, it would seem, entails that that defective E-ruler is nevertheless an E-ruler. A similarly defective T-ruler, in contrast, is no T-ruler at all.

Reeve, who denies that Thrasymachus ever holds to a conventionalist understanding of what it is to be an E-ruler, is ingeniously unfazed by these considerations, and offers an account of the progress of Thrasymachus' talk about rulers throughout $[\mathrm{A}]$ and $[\mathrm{B}]$ that, if correct, will allow one to dispense with the pre-fixes and find him to be talking simply about rulers:

it is simply false to say that Thrasymachus must be talking about E-rulers when he admits rulers make legislative errors. For part of what he does...is to represent such talk as loose. To say that 
rulers make legislative errors is not to talk precisely about E-rulers, he claims, but loosely about T-rulers. ${ }^{19}$

This then allows, indeed requires, one to find that $(\mathrm{E})$ itself is a claim about T-rulers. Reeve acknowledges that this might seem to be in tension with Thrasymachus' grounding it in empirical claims about the behaviour of those who actually have power in Greek states, but thinks that this too will be eased by understanding how Thrasymachus conceives of the relation between E-rulers and T-rulers:

If $\mathrm{E}$ is about T-rulers, however, in what sense, if any, can it be an empirical claim about the behaviour of rulers in actual Greek cities? While E- and T-rulers, laws, and the rest are excellent expository devices, it is a mistake to treat E-rulers as the sort we find in actual cities and make empirical claims about, and T-rulers as creatures of Thrasymachean ideal theory or fantasy, about whom we make a priori or conceptual claims. For Thrasymachus makes it quite clear that Trulers are E-rulers at those times when they are actually practising the craft of ruling, and so not making errors. When E-rulers are ruling correctly, they are T-rulers, therefore, and sotautologically—never make errors. ${ }^{20}$

We can compare this with Thrasymachus' own explanation of his initial response to Socrates' objection and his contrast between speaking of rulers loosely and precisely:

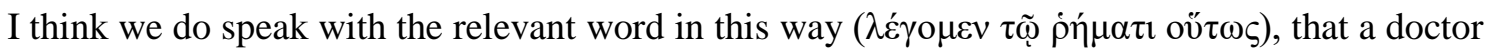
makes a mistake, or an accountant, or a grammarian. But each of these, insofar as he is what we

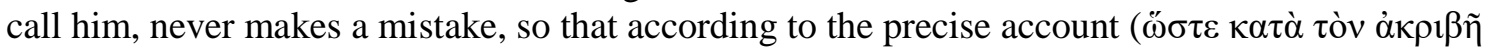

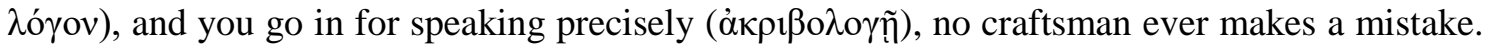
It's when his knowledge fails him that he makes an error, and in regard to that error he is no craftsman. No craftsman, wise man, or ruler makes a mistake at the moment when he is ruling, even though everyone will say that a doctor or a ruler makes mistakes. It's in this way that you

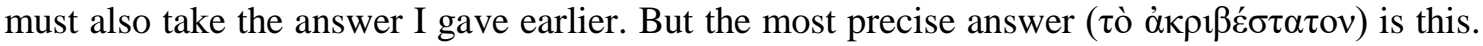
A ruler insofar as he is a ruler, never makes mistakes and unerringly decrees what is best for himself, and this his subject must do. Thus, as I said from the first, it is just to do what is to the advantage of the stronger. (340d-341a).

Thrasymachus thus contrasts the precise account of craftsmen, according to which it will not be true that a craftsman ever makes a mistake, with a looser way of using the terms for craftsmen where people will indeed say that a doctor or ruler or whoever does make mistakes. He acknowledges that his claims in [A] involved this looser usage, but that, now using the term 'ruler 'precisely, what he says will not allow the possibilities that Socrates has tried to deploy to block his argument. So, Reeve and Thrasymachus are certainly at one in their trying to explain away Thrasymachus' initial acceptance of rulers'

\footnotetext{
${ }^{19}$ Reeve, p. 89

${ }^{20}$ Reeve, p. 89 (all italics there are Reeve's).
} 
fallibility as the result mere loose speaking and in denying that in moving to talk more precisely he doesn't thereby change what he is talking about. What is at issue is whether their defence can be made good-and indeed whether in its details it is quite the same defence.

What, though, does it mean to say that Thrasymachus is talking loosely about Trulers at 339c? One might, it seems, effect a distinction between talking loosely and talking precisely about something in various ways. One way might be where one imprecisely applies what is a precise criterion for applying the relevant concept. So, one might describe a quickly drawn shape as a square, even though the angles in contains approximate to being right angles when in fact they aren't. Another might be where the criteria for applying a term loosely are sufficient for making a probable judgement that something falls under the concept but do not determine that it does-doing that will require some other or further criterion to be employed. So, a doctor might diagnose influenza on the basis of a patient's symptoms, but a certain diagnosis would require PCR testing. Doctors will commonly use 'flu' in that loose way, but still acknowledge that those they diagnose with flu may not actually have it. It is not that they've improperly or carelessly applied the criteria for precise diagnosis of a patient's infection, but that they've applied other criteria which are adequate for most practical purposes but are accepted to be insufficient to determine the truth of the diagnosis. Someone may have flu and yet be asymptomatic, so will not be found to have flu on the basis of the loose criteria, or may easily satisfy the loose criteria but not have flu.

It is clear, I think, that it is not the first kind of looseness of talk that is in question for Thrasymachus. He is not supposing that ordinarily, say, we will judge someone to be a doctor unless they are making a mistake but don't worry too much about whether they have actually made an error of diagnosis or treatment. His point is precisely that when we speak loosely we will say, and intelligibly so, that a doctor does make mistakes. The looseness, then, would need to be of the second kind. The idea, then, would be something like this. When Thrasymachus responds to Socrates' by tightening up the conditions for being a ruler, he does not determine a new concept but in effect argues that the existing concept itself, when properly understood, makes demands that are often neglected in our ordinary talk. Although ordinarily we are ready to talk as if rulers can make mistakes in legislating, more careful thought about what it is to be a ruler will show that this is in fact incoherent: when one grasps the conditions for being a ruler, one will see that they in fact preclude anyone who is making a legislative error from complying with it. 
Now, on Reeve's construal of the argument, someone will satisfy the predicate 'is a T-ruler' when they are actually exercising the craft of ruling. ${ }^{21}$ Anyone who is a T-ruler must also be an E-ruler: only those with the power for their laws to be enacted will be able to exercise that craft. So the notion of a T-ruler is certainly more restrictive than that of an E-ruler, but doesn't follow from this that it is a more precise one. It is not that the conditions for determining whether someone is an E-ruler are somehow indeterminate and in order to resolve that indeterminacy, one needs to appeal to the extra condition introduced with the concept of a T-ruler. Working out who are and who are not T-rulers will not revise one's judgements as to who are and who aren't E-rulers-indeed they presuppose such judgements have already successfully been made. There is nothing wrong with introducing the concept of a T-ruler and it may well be that there is some utility in being able to talk just of those rulers who are exercising their skill of ruling, but it would be a mistake to think that that concept allows one to do better what the concept of being an E-ruler could only imperfectly allow one to do.

It is instructive to compare this with Nicias' defence in the Laches of his proposal that courage can be identified as knowledge of future goods and harms. This is very much a revisionary account of what it is to be courageous and rests on an acceptance that people's ordinary grasp of a concept is imperfect in a way that leads them to make claims which cannot be true. Challenged by Laches with the objection that this would not allow animals to be counted as courageous, he is duly unimpressed:

By no means, Laches, do I call courageous wild beasts or anything else that, for lack of understanding, does not fear what should be feared. Rather I would call them rash and mad...

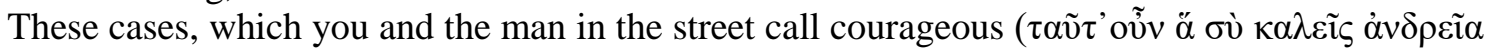

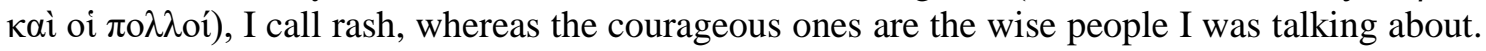
$(197 b-c)$

\footnotetext{
${ }^{21}$ In fact, Reeve's claim, cited above, that Thrasymachus makes it clear that someone is only a Truler when they're exercising the craft of ruling is at best optimistic. What Thrasymachus says is that one wouldn't call someone a ruler when they're making a mistake. This would allow them to be a ruler even when they're not exercising the craft as long as they possess the knowledge that would be exercised in legislating. Nawar points to Thrasymachus' claim at 340e that the craftsman makes an error when their knowledge fails them to argue that for Thrasymachus error is incompatible not just with the exercise of the craft but its possession. If one accepts that then the concept of a T-ruler will be that of an E-ruler who possesses the craft of ruling and not that of someone who is simply exercising the craft they possess. This merits a separate a more detailed discussion than I can offer here, but does not, I think, affect the structure of my discussion. Neither concept of T-ruler is one that is required to make something more precise of that of the E-ruler.
} 
People are ordinarily ready to say that lions and leopards are courageous - as, according to Thrasymachus, they are ready to say that rulers can make mistakes-but their willingness rests on a confused grasp of the concept of courage and what it is to comply with it. It is not that Nicias is trying to introduce a new technical notion of courage; rather he is making a claim as to the nature of courage itself, a claim whose truth can be obscured if we accept as a starting-point judgements as to who or what can be courageous that spring from an imperfect grasp of the concept.

As wehave seen, however, there's no reason to think that the concept of an E-ruler is an imperfect one-nor that Thrasymachus thinks that it is before he needs to introduce the supposedly more precise notion of a T-ruler in order to escape Socrates' trap. Here a couple of differences between Nicias and Thrasymachus are significant. Whilst Nicias offers an explanation of why people have the false beliefs they do about which creatures and people can be courageous - they are confusing courage with rashnessThrasymachus would provide no such palliative to his account. If we want to say that a ruler has enacted defective legislation, it turns out that we do not have the linguistic resources to do so and would have to coin a new term to do what we thought the existing term 'ruler' was already able to do. By distinguishing between 'ruler' used loosely and used precisely, that in effect is what, of course, Thrasymachus does and why, however cumbersome, the interpretative apparatus of 'E-ruler' and 'T-ruler' has continued to be necessary.

As importantly, Nicias has no need to interpret himself as having spoken loosely about courage. As soon as Socrates and Laches raise the question as to whether animals can be courageous, Nicias protests that they cannot. Thrasymachus, in contrast, immediately assents to the claim that rulers can make mistakes - and it is only when it is brought home to him that this then blocks his argument for (2) that he moves to restrict the notion of a E-ruler in the way he tries to do. This is difficult to square with the idea that Plato wants us to accept that Thrasymachus from the start takes the concept of a ruler to be that of a T-ruler. Had Plato wanted to show that Thrasymachus was operating with this technical notion, it would have been appropriate for him to have Socrates raise his objection; but then he would have had Thrasymachus respond immediately by denying its intelligibility, not by accepting its force. Instead of that, Thrasymachus not only allows the intelligibility of fallible rulers without hesitation, but accepts that rulers actually do make mistakes - and this is puzzling if the position he has enunciated is precisely that 
one should only obey laws passed by rulers who meet the strict conditions which he will go on to make explicit.

Indeed, until Thrasymachus moves to retract his admission that rulers can make mistakes, all the participants in the discussion take it as read that his conception of a ruler is simply that of someone who has the power to govern a state. Not only does Socrates assume that his argument is vulnerable to the obvious empirical fact that rulers do not always legislate successfully, but as soon as he has given this as an objection, both Polemarchus and Cleitophon take its force to be obvious. ${ }^{22}$ They differ only in that whilst Polemarchus thinks that it provides a knock-down rebuttal of Thrasymachus' conclusion, Cleitophon tries to save something from the wreckage by suggesting that Thrasymachus can retreat to the claim that justice is what the stronger believes to be to their advantage. When Thrasymachus asks, supposedly rhetorically, 'Do you think I'd call someone who is in error stronger at the very moment he errs?' (340c), the disdain in Socrates' answer is clear: 'I did think that is what you meant when you agreed that rulers aren't infallible but are liable to error'. Socrates thought that Thrasymachus believed this because that is just what he said.

Socrates rejects Thrasymachus' attempt to reinterpret what he's said so as to pretend he had said something other than he did. Indeed, Thrasymachus himself is half-hearted in his attempt to bluster since within a few lines he is rather seeking to explain away what he said as loose talk than to deny he said it at all. However, it will not do for him to try to wriggle out of this by saying that he was just talking in the way that people ordinarily do, nor for Reeve to try to rescue him by glossing this as his talking loosely about T-rulers. For if Thrasymachus had from the beginning endorsed a conception of rulers according to which someone is only a ruler when they are exercising their legislative skill, his answers to Socrates' questions were not only strictly but obviously false. Thrasymachus' opening claims, then, are about E-rulers — which is why he is initially perfectly prepared to allow them to be fallible - and the claim he defends against Socrates' objection concerns T-rulers. Himself using the same term to express these different concepts, Thrasymachus remains unaware that he has changed the subject.

\footnotetext{
${ }^{22}$ Reeve is right to say that one can in principle make empirical claims about T-rulers, so conceived, just as one can about E-rulers. It might turn out, for instance, that every T-ruler has a glint of satisfaction when they legislate. But one claim about them which could not be empirically given, because it is ruled out conceptually, is that they sometimes make mistakes in legislating. That would precisely undercut the condition for their being a T-ruler at all.
} 
There are, however, two aspects of my earlier treatment of Thrasymachus in IT that need correction; the first relatively minor and the second more substantive. If the present argument has been correct, Thrasymachus defends (1) by revising the argument he gives for it. In [A] it is secured by (2a), whilst in [B], (2a) is silently renounced, to be replaced by (2b). If we take Thrasymachus' position to be (1) together with the claims he makes to secure it, his position in $[\mathrm{B}]$ is neither the position of $[\mathrm{A}]$ nor consistent with it. There will be actions that will count as just according to [A] but not according to [B]. Nevertheless, it would be over-enthusiastic to maintain, as I myself did in IT, that when Thrasymachus apparently reaffirms (1) at 341a, he 'is now putting forward an account which is incompatible with the one he began with, but is using the same words to do so' (p. 124). This rested on appealing to Thrasymachus' retort at 340c: 'Do you think I'd call someone who is in error stronger at the very moment he errs?', which I took to introduce the notion of someone who is T-stronger, so that 'stronger', like 'ruler' is given a novel, more restrictive sense. One can, however, appreciate the force of Thrasymachus' question without needing to find that he is using 'stronger' in any other sense than he had done to this point. We can reasonably take his rejection of the boxer Polydamus as an example of someone who has the relevant kind of strength to indicate that the kind of strength he has in mind is that of being able to control the behaviour of others; a kind of strength exemplified by the rulers of states (E- or T-). He can readily claim that someone who tries but fails to regulate the behaviour of others to further his own interests does not manifest that kind of strength - so there is no need to find here the introduction of some new more restricted kind of strength. If that is right, then although Thrasymachus' position changes between $[\mathrm{A}]$ and $[\mathrm{B}]$, both provide arguments for the same conclusion - that justice is what is to the advantage of the stronger. ${ }^{23}$

${ }^{23}$ Ironically, Reeve himself could not allow that Thrasymachus consistently maintains (1) throughout, since he maintains that Thrasymachus takes the claim that someone is stronger to be equivalent to the claim that they are a ruler, or at least that he identifies the property of being stronger with the property of being a ruler (p. 92). If that were right, then the shift from (2a) to (2b) would change the sense of 'stronger', since the concept of being an E-ruler is distinct from that of being a T-ruler. Reeve also takes the 'is' in (1), (2) and (3) to express identity, whereas in (1) and (2) I take it to be predicative. There is not the space to explore that issue here, but I do so in 'Defining Justice in Republic I' (ms). 
At this point, it might seem that focusing on whether the position articulated in [A] is consistent with that of $[\mathrm{B}]$ is a distraction from the broader and more important issue as to whether (1) is consistent with the claim that justice is the good of another. In IT, I took it that in applying the normative constraints on who is to count as a ruler and what is to count as a law, Thrasymachus moves away from the conventionalism about justice which we find in [A] and which is both distinct from and inconsistent with the later immoralism, according to which justice is something independent of laws but is a bad rather than a good thing. A primary motivation for Reeve's attempt to show that Thrasymachus is talking about T-rulers and T-laws even in [A] is to remove any suggestion of conventionalism and so, he thinks, any block to reconciling the claims that justice is advantageous to the stronger and that it is the good of another. Whether or not the position of $[\mathrm{A}]$ is a conventionalist one, the more significant issue will be whether that of $[\mathrm{B}]$ is, since that is the position Thrasymachus ends up holding before he moves on to discuss the irrationality involved in the just person's acting with a view to the interests of other people. It may diminish our confidence in Thrasymachus if we find that his views change between $[\mathrm{A}]$ and $[\mathrm{B}]$ without his realising this — but so long as he does in fact abandon any commitment to conventionalism by the time he makes the further claim that justice is the good of another, his position at that point need not be straightforwardly inconsistent (as it would have been if he had not placed the conditions on being a ruler needed to counter Socrates' objection).

Of course, even if Thrasymachus were to have in [B] moved away from his initial conventionalism, this would not be sufficient to show that his views on the nature of justice are consistent overall-clearly not every account of justice that avoids conventionalism will be consistent with every other such account — but it is in any case dubious that [B] does in fact effect such a move. This is the second, and more significant, correction that needs to be made to the argument of IT. I effectively assumed there that, given (3), a positivist account of rulers and laws would simply run together with conventionalism about justice — so that Thrasymachus' abandonment in [B] of the first resulted in a similar move away from the second. There is, however, no straightforward route from the abandonment of a positivist account of rulers and laws to a nonconventionalist account of justice. For what secures Thrasymachus' conventionalism up to his advancing the claim that justice is the good of another is his continued adherence to (3) - that whatever laws a ruler enacts, justice is obeying these. Indeed, his appeal to the notions of T-rulers and T-laws to answer Socrates' objection to the argument of [A] 
is motivated by his desire not only to protect (1) but the conjunction of (1) with a version of (3). It would have been quite possible for Thrasymachus to have given up (3) as a ground for (1) and to have argued, for instance, that strength merits obedience, so that it is just to act in the interests of the stronger. Obeying laws that have been enacted by Trulers would then be a particular application of that more general principle of justice. ${ }^{24}$ This, however, would allow justice to stand as a prior and independent source of norms for deciding whether to obey any candidate law. Thrasymachus does not take that line: certainly, he places normative constraints on being a ruler and being a law, but although these then determine which actions justice requires - or perhaps rather which actions rulers would have us believe justice requires - they are not themselves requirements of justice.

Even in [B], that is, although whenever someone acts justly by acting as the laws require them to they will thereby act in the interests of the ruler, they can act in the interests of the ruler without acting justly. Because it is only necessary and not sufficient that an action should be in the interest of the ruler that it should be required by law, which kinds of action will be legally prescribed is still a matter of what the ruler happens to decide. If the ruler has not bothered to legislate to further their interest in some way, then, there will be no requirement either of law or of justice for the subject to act as if they had. Which of the actions, or kinds of action, that will be to the ruler's interest are required by law is up to the decision, indeed even the whim, of the legislator. The central conventionalist claim - that whether an action is just or not depends on which laws happen to be enacted-is untouched. Thrasymachus may introduce technical conceptions of rulers and laws in order to save his commitment to (1), but even this is not enough to bring his legalistic conception of justice into line with what follows from 343c, when he quietly abandons (3) and allows that the just person's willingness to obey the law is but one way in which they subordinate their interests to those of other people.

Stephen Everson

University of York

\footnotetext{
${ }^{24}$ So, this would seem to be the underlying position of those cited in the Laws who also adopt the slogan that 'justice is whatever is to the advantage of the stronger'. When the Athenian refers to them in Laws IV 714bff, he refers back to the discussion in Book III of what should ground authority in the state, and associates them with the view that 'the stronger should rule and the weaker should obey' - 'a decree of nature, as Pindar of Thebes once remarked' (690b).
} 


\section{Bibliography}

Annas, J. (1981) An Introduction to Plato's Republic, Oxford.

Austin, J. (1995) The Province of Jurisprudence Determined, ed. W.E. Rumble, Cambridge.

Everson, S. (1998) 'The Incoherence of Thrasymachus', Oxford Studies in Ancient Philosophy XVI: 99-131.

Everson, S. (2012) 'Justice and Just Actions in the Republic', in Morison, B. and Ierodiakonou, K (edd.), Episteme, etc., Oxford: 249-76.

Everson, S. (manuscript) 'Defining Justice in Republic I'.

Marmor, A. (2011) Philosophy of Law, Princeton and Oxford.

Nawar, T. (2018) 'Thrasymachus' Unerring Skill and the Arguments of Republic 1', Phronesis 63: 359-91.

Reeve, C. D. C. (1998) Philosopher-Kings, Princeton/Oxford.

Reeve, C. D. C. (2008) 'Glaucon's Challenge and Thrasymacheanism', Oxford Studies in Ancient Philosophy XXXIV: 69-103.

Wiggins, D. (2001) Sameness and Substance Renewed, Cambridge. 